\title{
Effects of Co-Culture of Graphene Oxide Scaffolds with Different Concentrations and Umbilical Mesenchymal Stem Cells on the Proliferation and Differentiation of Stem Cells
}

\author{
Aifeng Liu \\ Tianjin University of Traditional Chinese Medicine \\ Jixin Chen \\ Tianjin University of Traditional Chinese Medicine \\ Shuwei Gong \\ Tianjin University of Traditional Chinese Medicine \\ Qiang Wei ( $\nabla$ weiqiang@hebut.edu.cn ) \\ Hebei University of Technology

\section{Ye Yuan} \\ Hebei University of Technology https://orcid.org/0000-0002-1656-9053
}

\section{Research article}

Keywords: graphene oxide, mesenchymal stem cell, co-culture, scaffolds, knee osteoarthritis

Posted Date: March 18th, 2021

DOI: https://doi.org/10.21203/rs.3.rs-333641/v1

License: (c) (1) This work is licensed under a Creative Commons Attribution 4.0 International License.

Read Full License 


\section{Abstract}

Background: The main role of the scaffold materials is to enable cells to survive in the scaffold binding as while as to further promote their proliferation and differentiation ability. For mesenchymal stem cell, the scaffold could provide an environment for them to maintain their phenotype, and synthesize all necessary molecules and proteins. Generally, scaffold materials for stem cell need to possess basic characteristics such as high porosity, large surface area, surface rigidity and biodeg-radability. Thus, the two-dimensional graphene oxide (GO) with oxygen-containing functional groups may be suitable scaffold materials for mesenchymal stem cell culture. In this study, the effect of GO on the value-added differentiation activity of mesenchymal stem cell was systematically investigated.

Results: It was found that low concentration of GO and sufficient concentration of umbilical cord mesenchymal stem cells are suitable for the second Co-culture. Furthermore, the addition of hyaluronic acid will make this culture more evenly distributed.

Conclusions. The adsorption of GO on umbilical cord mesenchymal stem cells can also make the two closely linked, which avoids the impact of animal joint activities on cells.

\section{Background}

Recently, the significant advantages of graphene oxides (GO) used as cell scaffold materials have attracted tremendous interests due to their large surface areas, friendly biological compatibility and good hydrophility [1-5]. As an ideal seed cell in tissue en-gineering, mesenchymal stem cell (MSC) has been widely used in the field of regenera-tive medicine [6-11]. MSC has the effect of regulating local immunity and improving the inflammatory environment. At the same time, MSC is low in immunogenicity, which will not bring risks to transplantation [12-17]. Many early studies have con-firmed that MSC transplanted in damaged structures can promote the repair effect of damaged areas. Up to now, the possibility of GO combined with MSC as the cell scaf-fold has also been initially explored [18-22]. However, there are few related studies and bone marrow stromal cells (BMSC) are mostly used as seed cells in the research.

At present, umbilical cord mesenchymal stem cells (UCMSC) has been employed to try to replace bone marrow stromal cells (BMSC) [23-25]. On one hand, the hu-man-derived BMSC needs to puncture the human bone marrow, which brings pain, safety risks and ethical problems to the human to some extent. On the other hand, bone marrow-derived MSCs are actually very small in content. The extremely low propor-tion of MSCs in bone marrow as well as the low-activity have a great impact on the results of research. Although some studies have confirmed that in vitro cultured MSCs and GO are biocompatible, they are also limited to the observation of the effect of GO on MSC survival without further in-depth studies and specific dose-effect relation-ships. The dynamic knee joint is one of the most important structures that carries the human body's movements [26-28]. The joint cavity must maintain the stability of me-chanical and biochemical microenvironment. MSC inhibits the inflammatory response through paracrine effects. Meanwhile, MSC releases growth factors such as plate-let-derived growth factor 
(PDGF), transforming growth factor (TGF- $\beta$ ), vascular en-dothelial growth factor (VEGF) and insulin-like growth factor (IGF). These growth factors could improve the biochemical micro-environment of the knee joint and pro-mote repair of cartilage tissue damage.

The problems of cell flow and low cell survival rate can be effectively solved by using cell scaffolds. The GO scaffold with favorable hydrophility, biocompatibility, ductility and damping properties can increase the electrical activity of cells [29-31]. In addition to being equipped with MSC, GO scaffold can also be combined with sodium hyaluronic acid $(\mathrm{HA})$ to prepare materials with lubricating effect on the joint cavity. Furthermore, GO can also improve the joint as lubricants. Herein, in this experiment, the culture effect of UCMSC with GO was initially explored in order to provide a novel strategy for the treatment of osteoarthritis.

\section{Methods}

\subsection{Materials and instruments}

GO is purchased from C6G6Technology Co., Ltd, China. The basic characterization of GO is in the Supporting Information (Fig. S1 and Fig. S2). The 3rd or 4th generation human umbilical cord mesenchymal stem cells (Boya stem cell technology co. LTD). DMEM/F12 medium and HA injection $2.5 \mathrm{ml} /$ piece (Japan, H20050370). High-throughput multi-sample tissue grinding machine (Nanjing, Xianou Instrument Manufacturing Co., Ltd.). Electronic platform scale (Switzerland, Mettler Toledo). Constant temperature and humidity incubator (SHEL LAB in the United States). OLYMPUS photomicroscope (OLYMPUS in Japan). ADAM automatic cell counter (NanoEnTek, Korea).

\subsection{Mixture of $\mathrm{GO}$ and $\mathrm{HA}$}

GO is placed in a small reagent tube and put it into a tissue grinder. The control frequency is set as $70 \mathrm{~Hz}$ and the stop time is $60 \mathrm{~s}$. After the machine stops running, remove the reagent tube, put it into a centrifuge, and centrifuge Operation: According to the needs of the experiment, use an electronic balance to weigh the masses of gra-phene oxide required by 4 groups of $\mathrm{GO}$ solution, and put them into four small reagent tubes labeled with groups, put them on the ultraviolet operating table, and use $1 \mathrm{ml}$ without The pipette tip of the bacteria tube transfers a part of the HA injection in the unsealed syringe containing 2.5 $\mathrm{ml}$ of HA injection into a small reagent tube filled with GO. The GO combined HA solution is configured to two concentrations: $15 \mu \mathrm{g} / \mathrm{ml} \mathrm{GO}+0.5 \% \mathrm{HA}$ and $30 \mu \mathrm{g} / \mathrm{ml} \mathrm{GO}+0.25 \% \mathrm{HA}$. After mixing, use the pipette Transfer all the liquid guns to the large test tube cap, and then transfer the HA injection solution in the remaining syringes to the large test tube caps of the same group. Use the pipette head to mix them thoroughly and turn on the ultraviolet light., Perform UV sterilization for $35 \mathrm{~min}$, and then use a pipette to transfer the mixture in the large test tube cap into the original syringe.

\subsection{Isolation, culture and identification of human UCMSC}

Take a healthy full-term fetal umbilical cord, rinse it thoroughly with PBS, remove the umbilical arteriovenous vein under sterile conditions, cut the remaining interstitial tissue (Walton's gel) into 1.0-2.0 
$\mathrm{mm}$ size tissue blocks, and flatten the tissue blocks on In the cell culture flask, add an appropriate amount of DMEM/F12 culture solution containing $10 \%$ fetal bovine serum in volume, and place in $37^{\circ} \mathrm{C}$, $5 \% \mathrm{CO}_{2}$ volume in-cubator for incubation. Replace the culture solution according to the cell growth rate. When the cells have reached the bottom of the culture flask, remove the tissue blocks, pass them down according to the number of cells, observe with an inverted microscope and take a video. Take the $3 \mathrm{rd}$ or 4th generation human UCMSC, digest with $0.25 \%$ trypsin, centrifuge at $1200 \mathrm{r} / \mathrm{min}$ for 5 minutes, count the cells, and use about $2 \times 10$ cells per tube. Use $0.1 \%$ sodium azide and 0.5 Wash the cells twice with PBS, resuspend the cells in PBS, add mouse anti-rat CD34, CD45, CD90, and CD105 primary antibodies (1:50 dilution), leave them at $4{ }^{\circ} \mathrm{C}$ for $30 \mathrm{~min}$, wash them twice with PBS, add isocya-nate Rabbit antimouse IgG secondary antibody labeled with fluorescein thiocyanate, placed at $4{ }^{\circ} \mathrm{C}$ for $30 \mathrm{~min}$, washed twice with PBS, resuspended the cells with PBS without BSA, and detected cell surface markers CD34, CD45, CD90 and CD105 expression.

\subsection{Experimental grouping and processing}

The experiment was divided into 4 groups. GO was mixed with HA injection after being treated with a tissue grinder and a centrifuge, and a mixture of $10 \mu \mathrm{g} / \mathrm{ml}, 20 \mu \mathrm{g} / \mathrm{ml}, 30 \mu \mathrm{g} / \mathrm{ml}$ and $40 \mu \mathrm{g} / \mathrm{ml}$ was used as a culture medium. Mark the cells separately, divide the human UCMSC into four groups of approximately equal amounts, mark the serial numbers, and transfer them to the corresponding medium with a pipette for cul-tivation.

\subsection{Effect of the mixture of $\mathrm{GO}$ and $\mathrm{HA}$ injection on the proliferation of human UCMSC}

The four concentration mixtures were placed in 96-well culture plates, and $100 \mu \mathrm{L}$ of medium was added to each well. The inoculated 96 -well culture plate was placed in a constant temperature incubator (5\% $\mathrm{CO}_{2}, 100 \%$ humidity, and $37^{\circ} \mathrm{C}$ constant tem-perature) for 24 hours, and observed under continuous microscope.

\section{Results}

\subsection{Biocompatibility of GO and UCMSC}

To observe the cytotoxicity of GO to UCMSC, the specific method is: take P4 generation UCMSC cells and GO solid particles, and conduct group culture observation. The control group is a pure UCMSC culture group, and the UCMSC concentration is $5.0 \times 104 \mathrm{MSC} / \mathrm{ml}$; the experimental group is In the UCMSC + GO co-culture group, the cell concentration was also $5.0 \times 104 \mathrm{MSC} / \mathrm{ml}$; the $\mathrm{GO}$ pellet mass was $5 \mathrm{mg}$, after rela-tively mixing, inoculated into a 24 -well plate, inoculated 500 ul per well. Incubate overnight in a $37^{\circ} \mathrm{C}$, $5 \%$ CO2 incubator, continuously observe, and take photos for re-cording. Among them, Day-1, Day-3, Day5 and Day-7 are for CCK8 detection. Day-1, Day-3 and Day-7 for life and death staining. 
The cck8 test results in Fig. 1 and Fig. 2 showed that the cells had no proliferation within 7 days with the $5 \mathrm{mg} / \mathrm{ml}$ drug. As the $\mathrm{GO}$ concentration is too high, the cell sur-vival space is compressed, and the overall culture density is too high to cause cell death. High concentrations of GO can produce toxicity to cells and mediate cell apoptosis.

\section{2. In vitro culture of UCMSC and GO at different concentrations}

UCMSCs with concentrations of $8.0 \times 10^{4} / \mathrm{ml}, 4.0 \times 10^{4} / \mathrm{ml}$, and $2.0 \times 10^{4} / \mathrm{ml}$ were cul-tured in vitro with GO nanoparticles at a concentration of $30 \mu \mathrm{g} / \mathrm{ml}$, and P4 generation umbilical cord UCMSCs were mixed with GO Inoculate into a 24-well plate, inoculate 500 ul per well, inoculate 2 wells in parallel for each concentration. Incubate overnight in a $37^{\circ} \mathrm{C}, 5 \% \mathrm{CO}_{2}$ incubator, continuously observe and take photos for recording. Among them, Day-1, Day-3, Day-5 and Day-7 are for CCK8 detection. Day-1, Day-3 and Day-7 for life and death staining.

The cck8 test results from Fig. 3 to Fig. 6 showed that the proliferation degree of $8.0 \times 10^{4} / \mathrm{m}, 4.0 \times 10^{4} / \mathrm{ml}$, $2.0 \times 10^{4} / \mathrm{ml}$ plus $30 \mu \mathrm{g} / \mathrm{ml} \mathrm{GO}$ was lower than that of the control group. With the increase of stem cell concentration, $30 \mu \mathrm{g} / \mathrm{ml} \mathrm{GO}$ was the effect of MSC proliferation is reduced. Combining the images under the magnification lens and the stained images of life and death, the low concentration of UCMSC cells cannot well reflect the migration and proliferation effects in the low concentration of GO environment. It is considered that the effect of GO particles on the cells is limited to a certain distance If the cell density is too low, the distance between GO and the cells is too far, so GO and UCMSC can be cultured separately, which cannot form a co-cultivation environment. However, it does not mean that the higher the density of UCMSC, the better, and the higher the seeding density will cause cell death. Therefore, in general, GO particles need a low-concentration environment to ensure their safety, while UCMSC must at least ensure a certain concentration to form a co-cultivation system.

\section{3. In vitro co-culture of UCMSC and GO granular lubricant}

To observe the in vitro culture of UCMSC and GO granular lubricant. The inocu-lation density of UCMSC is $2.0 \times 104 / \mathrm{ml}$. The mixed concentration of GO granular lubri-cant is $15 \mu \mathrm{g} / \mathrm{ml} \mathrm{GO}+0.5 \% \mathrm{HA}$ and 30 $\mu \mathrm{g} / \mathrm{mlGO}+0.25 \% \mathrm{HA}$; Inoculate $0.5 \mathrm{ml}$ into each well, inoculate 2 wells in parallel at each concentration; incubate overnight in a $37^{\circ} \mathrm{C}, 5 \% \mathrm{CO} 2$ incubator, observe continuously and take pictures for recording.

The cck8 test results in Fig. 7 and Fig. 8 showed that within 72 hours, the prolifer-ation of $15 \mu \mathrm{g} / \mathrm{ml} \mathrm{GO}+$ $0.5 \% \mathrm{HA}$ and $30 \mu \mathrm{g} / \mathrm{ml} \mathrm{GO}+0.25 \% \mathrm{HA}$ was lower than that of the control group, and with the increase of GO concentration, the degree of MSC pro-liferation decreased. On the 5th day, the stem cell proliferation of the $15 \mu \mathrm{g} / \mathrm{ml} \mathrm{GO}+0.5 \% \mathrm{HA}$ group was higher than that of the control group. The CCK8 value of the 15 $\mu \mathrm{g} / \mathrm{ml} \mathrm{GO}+0.5 \% \mathrm{HA}$ group was 1.160 and that of the control group was 1.121; the proliferation degree of 
$30 \mu \mathrm{g} / \mathrm{ml} \mathrm{GO}+0.25 \%$ HA was higher than that of the control Group is low, as the GO concentration decreases, the degree of MSC proliferation increases. On the 7th day, the stem cell proliferation of the 15 $\mu \mathrm{g} / \mathrm{ml} \mathrm{GO}+0.5 \% \mathrm{HA}$ group was higher than that of the control group. The cck8 value of the $15 \mu \mathrm{g} / \mathrm{ml} \mathrm{GO}$ $+0.5 \%$ HA group was 1.169 and that of the control group was 1.111; the proliferation degree of 30 $\mu \mathrm{g} / \mathrm{mlGO}+0.25 \% \mathrm{HA}$ was higher than that of the control group, as the $\mathrm{GO}$ concentration decreases, the degree of MSC proliferation increases. The proliferation of stem cells in the $15 \mu \mathrm{g} / \mathrm{ml} \mathrm{GO}+0.5 \% \mathrm{HA}$ group in group $\mathrm{C}$ was higher than that in the con-trol group. It may be that the stem cells in the control group have proliferated to the maximum value and have been lost. Therefore, the cck8 value decreased from 1.121 to 1.111 at 5 th day. The adsorption effect of GO on stem cells, the growth surface area in the well plate is larger than that of the control group, so the degree of stem cell proliferation is higher than that of the control group. The ratio of the mixed lubricant of $\mathrm{GO}$ and $\mathrm{HA}$ is also related to the cultivation of UCMSC. First of all, because sodium hyaluronate injection is a kind of macromolecular structure, it has high viscosity, theoretically, it will have a certain impact on the migration of MSC and hinder its aggregation to GO particles, so the concentration of HA should not be too high. However, HA will also hinder the aggregation of GO particles, which is conducive to the uniform distribution of GO particles. The results also show this. Small particles of GO will be safer and less toxic than large particles of GO. Therefore, the mixing of $\mathrm{HA}$ is conducive to the long-term uniform distribution of UCMSC $+\mathrm{GO}$, and from the results, the low con-centration of HA is more suitable for co-cultivation of the two.

\section{Discussions}

\subsection{Serum NO test results}

The difference between GO + MSC group and blank group in group A was statistically significant $(\mathrm{P}<$ $0.01)$, and there was no significant difference between MSC group, GO group and blank group $(P>0.05)$. The difference was not statistically significant $(P>0.05)$. The difference between $G O+M S C$ group and blank group in group $B$ was statistically significant $(P<0.01)$, the difference between MSC group, GO group and blank group was statistically significant $(P<0.05)$. The difference between $G O+M S C$ group and MSC group was It has statistical significance $(P<0.05)$. Compared between groups, the difference between GO + MSC group, MSC group and GO group was not statistically significant $(P>0.05)$, and the difference between blank group was statistically significant $(P<0.05)$ (Table 1).

Table 1

Serum NO results after treatment $(\overline{\mathrm{x}} \pm \mathrm{s}, \mathrm{ng} / \mathrm{ml})$.

\begin{tabular}{|lllll|}
\hline Group & Blank & GO & MSC & GO + MSC \\
\hline Group A & $22.097 \pm 0.352$ & $21.436 \pm 0.031^{1)}$ & $21.020 \pm 0.026^{2)}$ & $17.624 \pm 0.127^{3)}$ \\
\hline Group B & $23.662 \pm 0.056$ & $20.544 \pm 0.085^{4)}$ & $19.424 \pm 0.046^{5)}$ & $17.799 \pm 0.049^{6)}$ \\
\hline P value & 0.029 & 0.430 & 0.254 & 0.725 \\
\hline
\end{tabular}

\subsection{Serum COL-II test results}


Within group comparison, the difference between GO + MSC group, MSC group and blank group in group A was statistically significant $(P<0.01)$, and the difference between $G O$ group and blank group was not statistically significant $(P>0.05) ; G O+M S C$ The difference between the group and the MSC group was statistically significant $(P<0.01)$. In group $B$, the difference between $G O+M S C$ group and blank group was statistically significant $(P<0.01)$, the difference between MSC group, GO group and blank group was not statistically significant $(P>0.05) ; G O+M S C$ group and MSC group. The difference was statistically significant $(P<0.01)$.

Compared between groups, the difference between GO + MSC group and MSC group was statistically significant $(P<0.01)$, and the difference between $G 0$ group and blank group was not statistically significant $(P>0.05)$ (Table 2).

Table 2

Serum COL-II results after treatment $(\overline{\mathrm{x}} \pm \mathrm{s}, \mathrm{ng} / \mathrm{ml})$.

\begin{tabular}{|lllll|}
\hline Group & Blank & GO & MSC & GO + MSC \\
\hline Group A & $13.475 \pm 0.342$ & $14.127 \pm 0.102^{1)}$ & $15.589 \pm 0.063^{2)}$ & $19.372 \pm 0.063^{3)}$ \\
\hline Group B & $12.253 \pm 0.147$ & $13.644 \pm 0.028^{4)}$ & $14.429 \pm 0.092^{5)}$ & $16.257 \pm 0.416^{6)}$ \\
\hline P value & 0.315 & 0.249 & 0.009 & 0.000 \\
\hline
\end{tabular}

\subsection{Serum GAG test results}

In group $\mathrm{A}$, the difference between $\mathrm{GO}+\mathrm{MSC}$ group and blank group was statistically significant $(\mathrm{P}<$ $0.01)$, the difference between MSC group and blank group was statistically significant $(P<0.05)$, and the difference between $G O$ group and blank group was not statistically significant. Significance $(P>0.05)$. The difference between GO + MSC group and MSC group was statistically significant $(P<0.01)$. In group $\mathrm{B}$, the difference between $\mathrm{GO}+\mathrm{MSC}$ group, MSC group and blank group was statistically significant $(\mathrm{P}<$ $0.01)$, the difference between $G O$ group and blank group was statistically significant $(P<0.05)$; comparison between GO + MSC group and MSC group. The difference was statistically significant $(\mathrm{P}<$ 0.05).

Compared between groups, the difference between the blank group and the GO + MSC group was statistically significant $(P<0.01)$, and the difference between the MSC group and the GO group was not statistically significant $(P>0.05)$ (Table 3$)$. 
Table 3

Serum $\mathrm{GAG}$ results after treatment $(\overline{\mathrm{x}} \pm \mathrm{s}, \mathrm{ng} / \mathrm{ml})$.

\begin{tabular}{|lllll|}
\hline Group & Blank & GO & MSC & GO + MSC \\
\hline Group A & $23.832 \pm 0.891$ & $26.342 \pm 1.042^{1)}$ & $29.022 \pm 0.973^{2)}$ & $37.439 \pm 2.155^{3)}$ \\
\hline Group B & $18.709 \pm 0.552$ & $22.689 \pm 0.641^{4)}$ & $24.028 \pm 0.675^{5)}$ & $26.554 \pm 0.450^{6)}$ \\
\hline P Value & 0.002 & 0.096 & 0.051 & 0.000 \\
\hline
\end{tabular}

\subsection{Serum IL-6 test results}

In group A, the difference between GO + MSC group, MSC group, GO group and blank group was statistically significant $(P<0.01)$; the difference between $G O+M S C$ group and MSC group was statistically significant $(P<0.01)$. In group $B$, the difference between $G O+M S C$ group, MSC group, $G O$ group and blank group was statistically significant $(P<0.01)$; the difference between $G O+M S C$ group and MSC group was statistically significant $(P<0.05)$.

Compared between different groups, the difference between GO + MSC group was statistically significant $(P<0.01)$, the difference between blank group was statistically significant $(P<0.05)$, the difference between MSC group and GO group was not statistically significant $(P>0.05)$ (Table 4).

Table 4

Result of serum IL-6 after treatment ( $\overline{\mathrm{x}} \pm \mathrm{s}, \mathrm{ng} / \mathrm{ml})$.

\begin{tabular}{|lllll|}
\hline Group & Blank & GO & MSC & GO+MSC \\
\hline Group A & $16.082 \pm 0.323$ & $10.957 \pm 0.343^{1)}$ & $9.668 \pm 0.194^{2)}$ & $7.426 \pm 0.294^{3)}$ \\
\hline Group B & $18.367 \pm 0.861$ & $10.002 \pm 0.191^{4)}$ & $9.506 \pm 0.123^{5)}$ & $8.680 \pm 0.242^{6)}$ \\
\hline P Value & 0.024 & 0.169 & 0.565 & 0.009 \\
\hline
\end{tabular}

\subsection{Serum TNF-a test results}

In group A, the difference between GO + MSC group, MSC group, GO group and blank group was statistically significant $(P<0.01)$; the difference between $G O+M S C$ group and MSC group was statistically significant $(P<0.01)$. In group $B$, the difference between $G O+M S C$ group, MSC group, GO group and blank group was statistically significant $(P<0.01)$; the difference between $G O+$ MSC group and MSC group was statistically significant $(P<0.05)$. 
Table 5

Result of serum TNF-a after treatment $(\overline{\mathrm{X}} \pm \mathrm{s}, \mathrm{ng} / \mathrm{ml})$.

\begin{tabular}{|lllll|}
\hline Group & Blank & GO & MSC & GO + MSC \\
\hline Group A & $9.466 \pm 0.177$ & $8.447 \pm 0.113^{1)}$ & $6.109 \pm 0.044^{2)}$ & $5.139 \pm 0.183^{3)}$ \\
\hline Group B & $10.013 \pm 0.197$ & $8.891 \pm 0.188^{4)}$ & $6.856 \pm 0.160^{5)}$ & $6.210 \pm 0.058^{6)}$ \\
\hline P Value & 0.037 & 0.087 & 0.146 & 0.006 \\
\hline
\end{tabular}

Compared between different groups, the difference between GO + MSC group was statistically significant $(P<0.01)$, the difference between blank group was statistically significant $(P<0.05)$, the difference between MSC group and GO group was not statistically significant $(P>0.05)$ (Table 5).

\section{Conclusions}

It was found that low concentration of GO and sufficient concentration of UCMSC are suitable for the second Co-culture. Furthermore, the addition of HA will make this culture more evenly distributed. The adsorption of GO on UCMSC can also make the two closely linked, which avoids the impact of animal joint activities on cells. Meanwhile, two subsequent knee osteoarthritis (KOA) animal models were selected in this experiment. The modified Hulth + cartilage defect model in group A is the main sports injury model. For the current multiple ligament tears and meniscus destruction, this injury will cause the intra-articular inflammation to gradually develop into sub-sequent KOA. The results show that the role of the three-dimensional mesh scaffold of this kind of GO particles is more important, which makes UCMSC better adhere to the cartilage defect area, so as to grow and proliferate. The model of group B is a model of cartilage degeneration induced by chemical factors. It can be seen that cartilage has different degrees of necrosis, which is relatively close to the pathogenesis of degenerative osteoarthritis in clinic. GAG, IL-6, and TNF-a have a statistically significant difference compared with the blank group, which also shows that the use of GO particle lubricants to carry UCMSC has a better therapeutic effect. In summary, we have con-firmed that GO can coexist with UCMSC in vitro and play the role of adsorption and promotion. Cell survival and growth under different concentrations of environment were preliminary discussed. UCMSC loaded with graphene oxide can promote the chondrocyte secretion of two knee osteoarthritis animal models, reduce the level of inflammation in the joints, and play a role in cartilage repair. Our findings may provide some help for the efficacy of KOA animal models exploration.

\section{Declarations}

\section{Ethics approval and consent to participate}

The experimental protocol was established, according to the ethical guidelines of the Helsinki Declaration and was approved by the Human Ethics Committee of First Teaching Hospital of Tianjin University of Traditional Chinese Medicine. Written informed consent was obtained from individual participants. 


\section{Consent for publication}

Not applicable.

\section{Availability of data and materials}

The data that supports the findings of this study are available within the manuscript and its supplementary material.

\section{Abbreviations}

Not applicable

\section{Competing interests}

All the authors declare no conflicts on financial interests of the manuscript.

\section{Funding}

This work was supported by the Natural Science Foundation of China (81873316 and 81673994), and Higher Education Science and Technology Research Project of Hebei Province (ZD2019087).

\section{Authors' contributions}

Aifeng Liu came up the basic ideas and analyzed the data of this manuscript. Jixin Chen conducted this experiment. Shuwei Gong also conducted this experiment. Qiang Wei supervised this research work. Ye Yuan were major contributors in writing the manuscript. All authors read and approved the final manuscript.

\section{Acknowledgements}

Corresponding authors: Qiang Wei and Ye Yuan

\section{References}

1. Holt BD, Wright ZM, Arnold AM, Sydlik SA. Graphene oxide as a scaffold for bone regeneration. WIREs Nanomedicine Nanobiotechnology. 2017;9:e1437. doi:10.1002/wnan.1437.

2. Shuai C, Zeng Z, Yang Y, Qi F, Peng S, Yang W, He C, Wang G, Qian G. Graphene oxide assists polyvinylidene fluoride scaffold to reconstruct electrical microenvironment of bone tissue. Materials Design. 2020;190:108564. doi:10.1016/j.matdes.2020.108564.

3. Serrano MC, Patiño J, García-Rama C, Ferrer ML, Fierro JLG, Tamayo A, Collazos-Castro JE, del Monte F, Gutiérrez MC. 3D free-standing porous scaffolds made of graphene oxide as substrates for neural cell growth. Journal of Materials Chemistry B. 2014;2:5698-706. doi:10.1039/c4tb00652f. 
4. Rostami F, Tamjid E, Behmanesh M. Drug-eluting PCL/graphene oxide nanocomposite scaffolds for enhanced osteogenic differentiation of mesenchymal stem cells. Materials Science Engineering: C 2020, 111102. doi:10.1016/j.msec.2020.111102.

5. Guo W, Qiu J, Liu J, Liu H. Graphene microfiber as a scaffold for regulation of neural stem cells differentiation. Sci Rep 2017, 7, 5678. doi: 10.1038/s 41598-017-06051z.

6. Pittenger MF, Mackay AM, Beck SC, Jaiswal RK, Douglas R, Mosca JD, Moorman MA, Simonetti DWJWR, Craig S, Marshak DR. Multilineage potential of adult human mesenchymal stem cells. Science. 1999;284:143-7. doi:10.1126/science.284.5411.143.

7. Dominici M, Blanc KL, Mueller I, Slapercortenbach I, Marini FC, Krause DS, Deans R, Keating A, Prockop DJ, Horwitz EM. Minimal criteria for defining multipotent mesenchymal stromal cells. The International Society for Cellular Therapy position statement. Cytotherapy. 2006;8:315-7. doi:10.1080/14653240600855905.

8. Zuk PA, Zhu M, Ashjian P, De Ugarte DA, Huang JI, Mizuno H, Alfonso Z, Fraser JK, Benhaim P, Hedrick MH. Human Adipose Tissue Is a Source of Multipotent Stem Cells. Mol Biol Cell. 2002;13:4279-95. doi:10.1091/mbc.e02-0105.

9. Jiang Y, Jahagirdar BN, Reinhardt RL, Schwartz RE, Keene CD, Ortizgonzalez XR, Reyes M, Lenvik T, Lund TC, Blackstad M. Pluripotency of mesenchymal stem cells derived from adult marrow. Nature. 2002;418:41-9. doi:10.1038/Nature00870.

10. Mani SA, Guo W, Liao MJ, Eaton EN, Ayyanan A, Zhou AY, Brooks MW, Reinhard F, Zhang CC, Shipitsin M. The epithelial-mesenchymal transition generates cells with properties of stem cells. Cell. 2008;133:704-15. doi:10.1016/j.cell.2008.03.027.

11. Prockop DJ. Marrow Stromal Cells as Stem Cells for Nonhematopoietic Tissues. Science. 1997;276:71-4. doi:10.1126/science.276.5309.71.

12. Caplan Al. Mesenchymal stem cells. J Orthop Res. 1991;9:641-50. doi:10.1002/jor.1100090504.

13. Aggarwal S, Pittenger MF. Human mesenchymal stem cells modulate allogeneic immune cell responses. Blood. 2005;105:1815-22. doi:10.1182/blood-2004-04-1559.

14. Kern S, Eichler H, Stoeve J, Kluter H, Bieback K. Comparative analysis of mesenchymal stem cells from bone marrow, umbilical cord blood, or adipose tissue. Stem Cells. 2006;24:1294-301. doi:10.1634/stemcells.2005-0342.

15. Blanc KL, Rasmusson I, Sundberg B, Gotherstrom C, Hassan M, Uzunel M, Ringden O. Treatment of severe acute graft-versus-host disease with third party haploidentical mesenchymal stem cells. The Lancet. 2004;363:1439-41. doi:10.1016/S0140-6736(04)16104-7.

16. Crisan M, Yap S, Casteilla L, Chen CW, Corselli M, Park TS, Andriolo G, Sun B, Zheng B, Zhang L. A Perivascular Origin for Mesenchymal Stem Cells in Multiple Human Organs. Cell Stem Cell. 2008;3:301-13. doi:10.1016/j.stem.2008.07.003.

17. Sato T, Vries RGJ, Snippert HJ, De Wetering MV, Barker N, Stange DE, Van Es JH, Abo A, Kujala P, Peters PJ. Single Lgr5 stem cells build crypt-villus structures in vitro without a mesenchymal niche. Nature. 2009;459:262-5. doi:10.1038/nature07935. 
18. Lee WC, Lim CHYX, Shi H, Tang LAL, Wang Y, Lim CT, Loh KP. Origin of Enhanced Stem Cell Growth and Differentiation on Graphene and Graphene Oxide. ACS Nano 2011, 5, 7334-41. doi: 10.1021/nn 202190c.

19. Tatavarty R, Ding H, Lu G, Taylor R, Bi X. Synergistic acceleration in the osteogenesis of human mesenchymal stem cells by graphene oxide-calcium phosphate nanocomposites. Chem Commun. 2014;50:8484-7. doi:10.1039/c4cc02442g.

20. Kim J, Kim HD, Park J, Lee E, Kim E, Lee S, Yang J, Lee Y, Hwang NS. Enhanced osteogenic commitment of murine mesenchymal stem cells on graphene oxide substrate. Biomaterials Research. 2018;22:1-9. doi:10.1186/s40824-017-0112-8.

21. Wang Z, Shen H, Song S, Zhang L, Chen W, Dai J, Zhang Z. Graphene Oxide Incorporated PLGA Nanofibrous Scaffold for Solid Phase Gene Delivery into Mesenchymal Stem Cells. Journal of Nanoscience Nanotechnology. 2018;18:2286-93. doi:10.1166/jnn.2018.14362.

22. Yang J, Hsieh KY, Kumar PV, Cheng S, Lin Y, Shen Y, Chen G. Enhanced Osteogenic Differentiation of Stem Cells on Phase-Engineered Graphene Oxide. ACS Appl Mater Interfaces. 2018;10:12497-503. doi:10.1021/acsami.8b02225.

23. Kim S, Han H, Chae G, Lee S, Bo S, Yoon J, Lee YS, Lee K, Park H, Kang K. Successful Stem Cell Therapy Using Umbilical Cord Blood-Derived Multipotent Stem Cells for Buerger's Disease and Ischemic Limb Disease Animal Model. Stem Cells. 2006;24:1620-6. doi:10.1634/stemcells.20050365.

24. Nicola MD, Carlostella C, Magni M, Milanesi M, Longoni P, Matteucci P, Grisanti S, Gianni AM. Human bone marrow stromal cells suppress T-lymphocyte proliferation induced by cellular or nonspecific mitogenic stimuli. Blood. 2002;99:3838-43. doi:10.1182/blood.V99.10.3838.

25. Nagasawa T, Hirota S, Tachibana K, Takakura N, Nishikawa S, Kitamura Y, Yoshida N, Kikutani H, Kishimoto T. Defects of B-cell lymphopoiesis and bone-marrow myelopoiesis in mice lacking the CXC chemokine PBSF/SDF-1. Nature. 1996;382:635-8. doi:10.1038/382635a0.

26. Ewald FC. The Knee Society total knee arthroplasty roentgenographic evaluation and scoring system. Clin Orthop Relat Res. 1989;248:9-12. doi:10.1007/978-1-4471-5451-8_47.

27. Girgis FG, Marshall JL, Monajem A. The Cruciate Ligaments of the Knee Joint: Anatomical. Functional and Experimental Analysis. Clin Orthop Relat Res. 1975;106:216-31. doi:10.1097/00003086-197501000-00033.

28. Insall JN, Salvati EA. Patella position in the normal knee joint. Radiology. 1971;101:101-4. doi:10.1148/101.1.101.

29. Hernandez Y, Nicolosi V, Lotya M, Blighe FM, Sun Z, De S, Mcgovern IT, Holland B, Byrne MT, Gunko YK. High-yield production of graphene by liquid-phase exfoliation of graphite. Nat Nanotechnol. 2008;3:563-8. doi:10.1038/nnano.2008.215.

30. Elias DC, Nair R, Mohiuddin T, Morozov SV, Blake P, Halsall MP, Ferrari A, Boukhvalov DW, Katsnelson MI, Geim AK. Control of Graphene's Properties by Reversible Hydrogenation: Evidence for Graphane. Science. 2009;323:610-3. doi:10.1126/science.1167130. 
31. Kudin KN, Ozbas B, Schniepp HC, Prudhomme RK, Aksay IA, Car R. Raman spectra of graphite oxide and func-tionalized graphene sheets. Nano Lett. 2008;8:36-41. doi:10.1021/nl071822y.

\section{Figures}

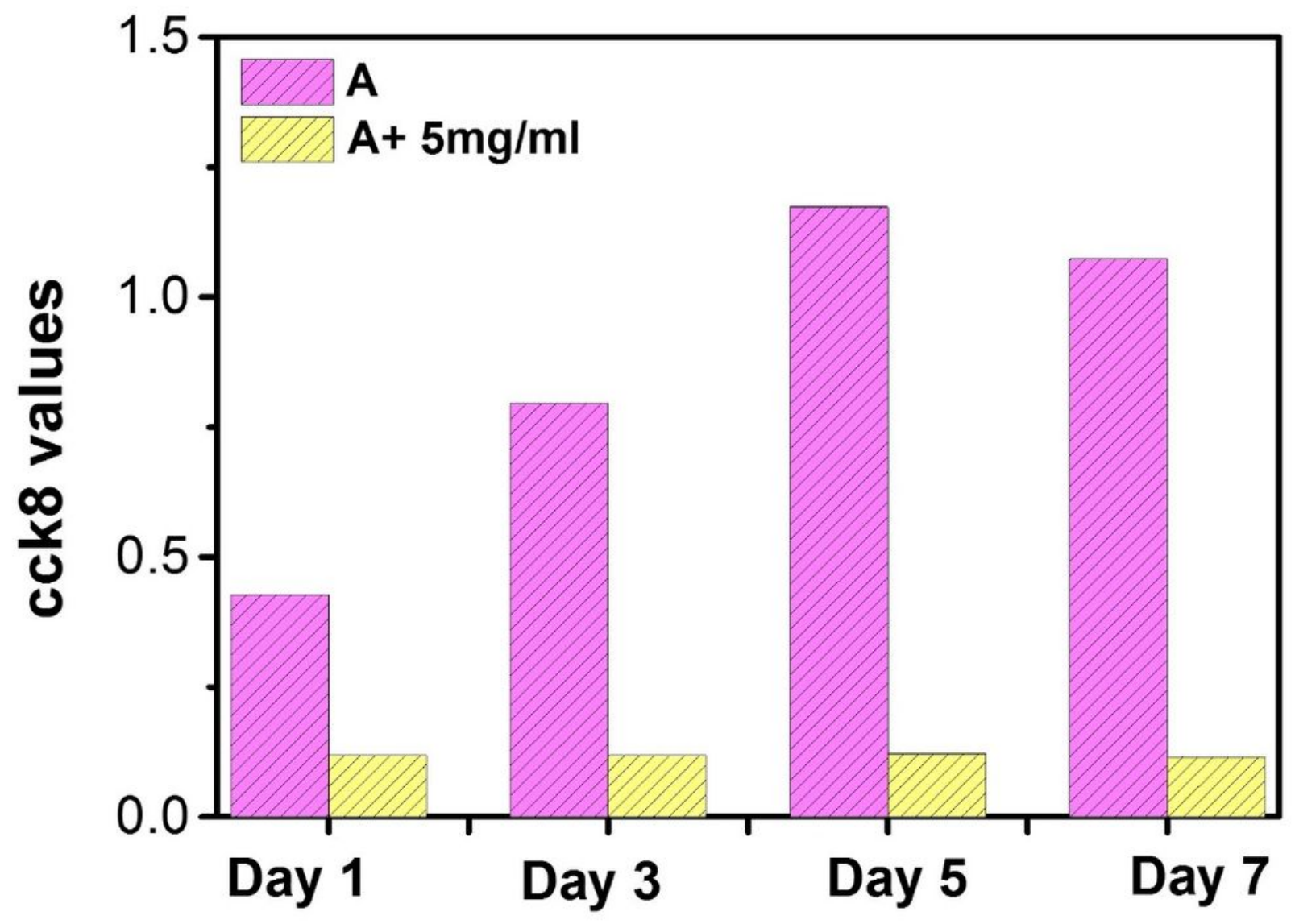

Figure 1

The cck8 detection values trend of group A and group A+GO after 7 days of culture. In both groups, the UCMSC cell concentration was $5.0 \times 104 / \mathrm{ml}$. The concentration of GO solution was $5 \mathrm{mg} / \mathrm{ml}$. 


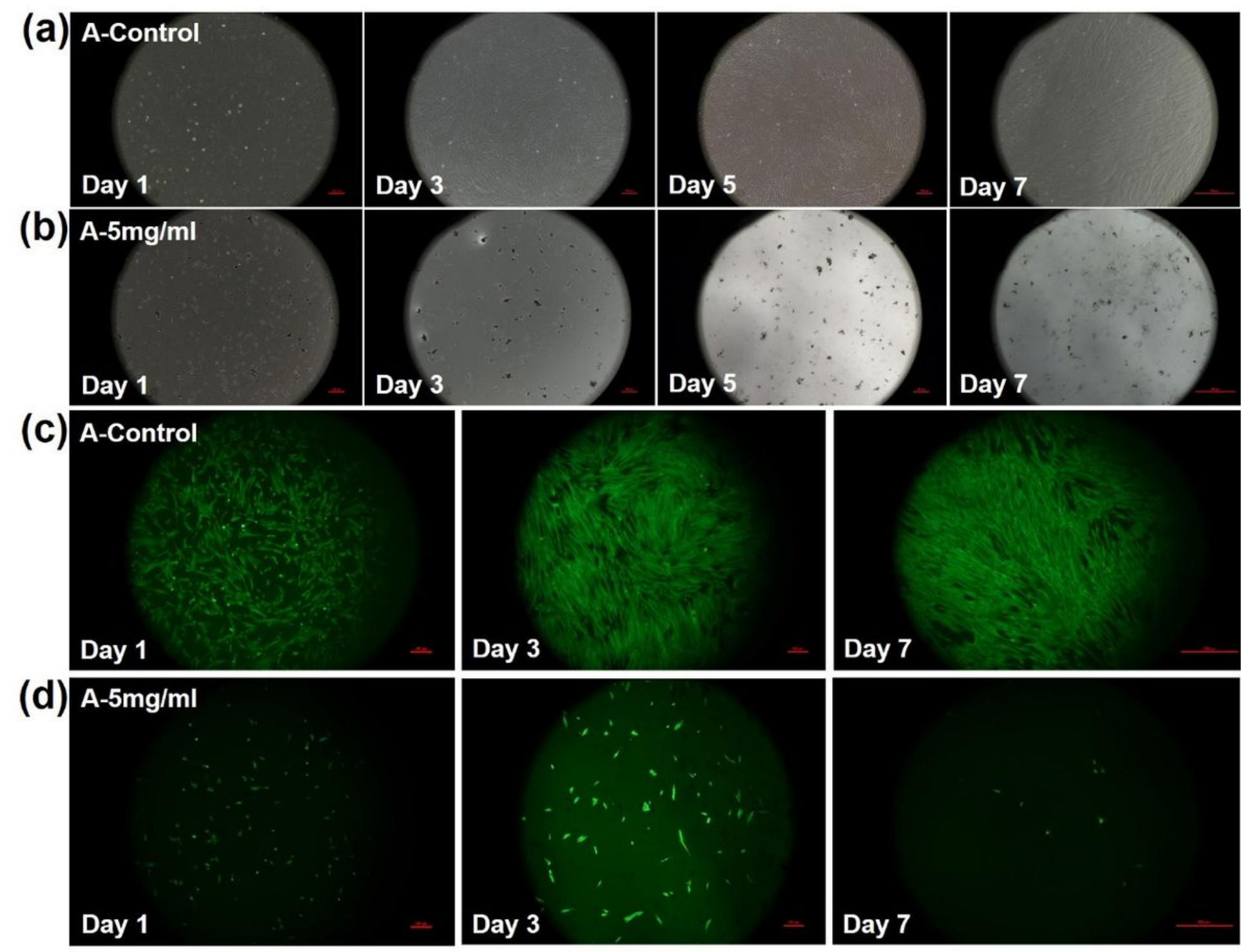

Figure 2

. Transmitted light images and fluorescence images of group A and group A+GO in 7 days of culture. (a) Transmitted light images of group A $(5.0 \times 104 / \mathrm{ml})$. (b) Transmitted light images of group A $(5.0 \times 104 / \mathrm{ml})$ $+\mathrm{GO}(5 \mathrm{mg} / \mathrm{ml})$. (c) Fluorescence images of group A $(5.0 \times 104 / \mathrm{ml})$. (d) Flu-orescence images of group A $(5.0 \times 104 / \mathrm{ml})+\mathrm{GO}(5 \mathrm{mg} / \mathrm{ml})$.
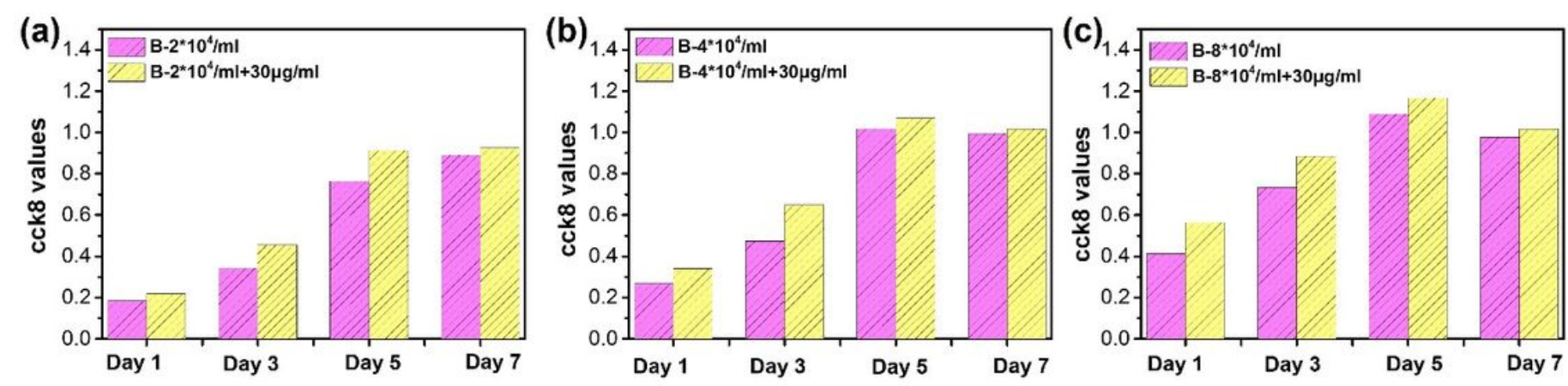


\section{Figure 3}

The cck8 detection values trend after 7 days of culture. (a) Group B $(2.0 \times 104 / \mathrm{ml})$ and group B $(2.0 \times 104 / \mathrm{ml})+\mathrm{GO}(30 \mu \mathrm{g} / \mathrm{ml})$. (b) Group B $(4.0 \times 104 / \mathrm{ml})$ and group B $(4.0 \times 104 / \mathrm{ml})+\mathrm{GO}(30 \mu \mathrm{g} / \mathrm{ml})$. (c) Group B $(8.0 \times 104 / \mathrm{ml})$ and group B $(8.0 \times 104 / \mathrm{ml})+\mathrm{GO}(30 \mu \mathrm{g} / \mathrm{ml})$.

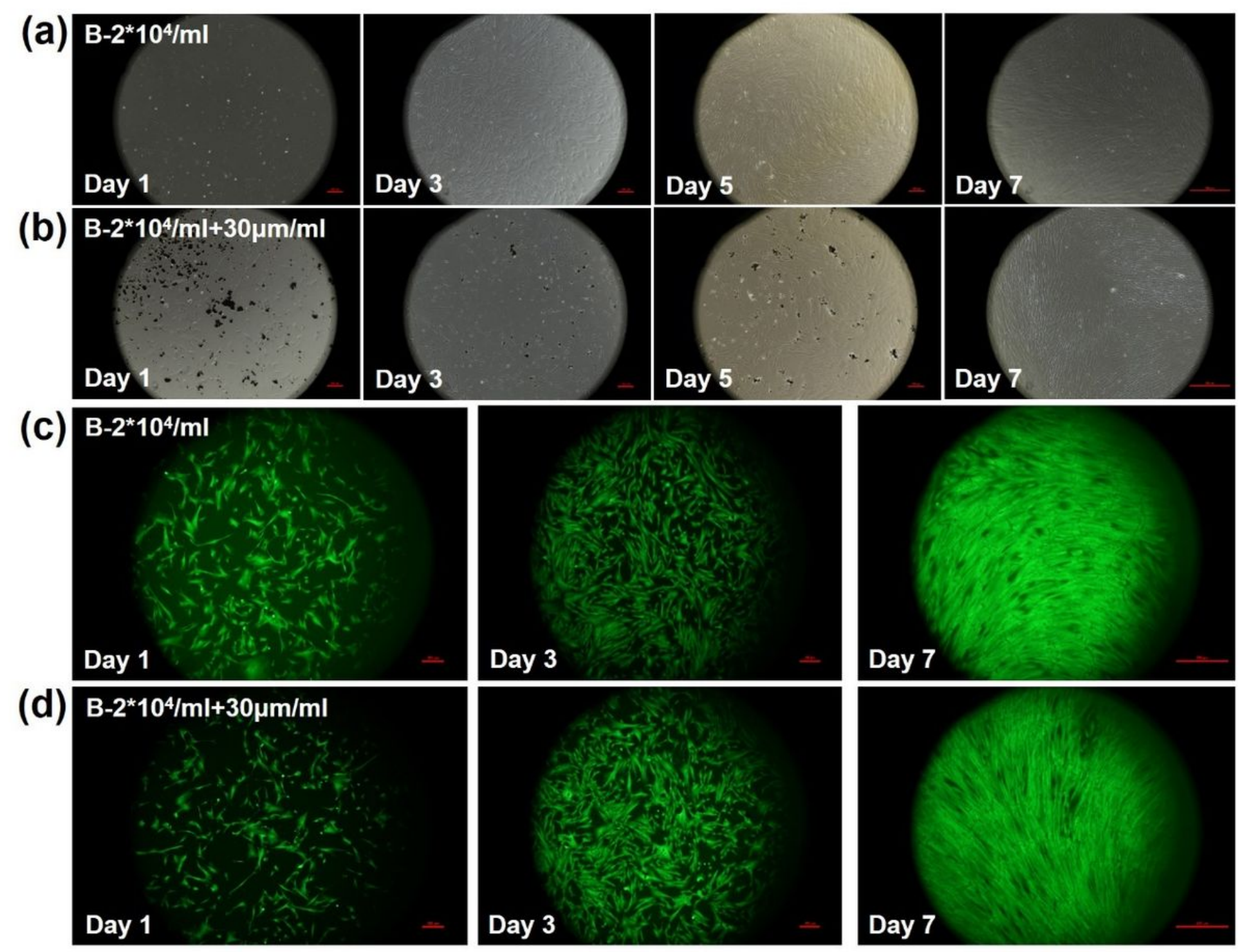

Figure 4

Transmitted light images and fluorescence images of group B and group B + GO in 7 days of culture. (a) Transmitted light images of group B $(2.0 \times 104 / \mathrm{ml})$. (b) Transmitted light images of group B $(2.0 \times 104 / \mathrm{ml})$ $+\mathrm{GO}(30 \mu \mathrm{g} / \mathrm{ml})$. (c) Fluorescence images of group B $(2.0 \times 104 / \mathrm{ml})$. (d) Fluorescence images of group B $(2.0 \times 104 / \mathrm{ml})+\mathrm{GO}(30 \mu \mathrm{g} / \mathrm{ml})$. 


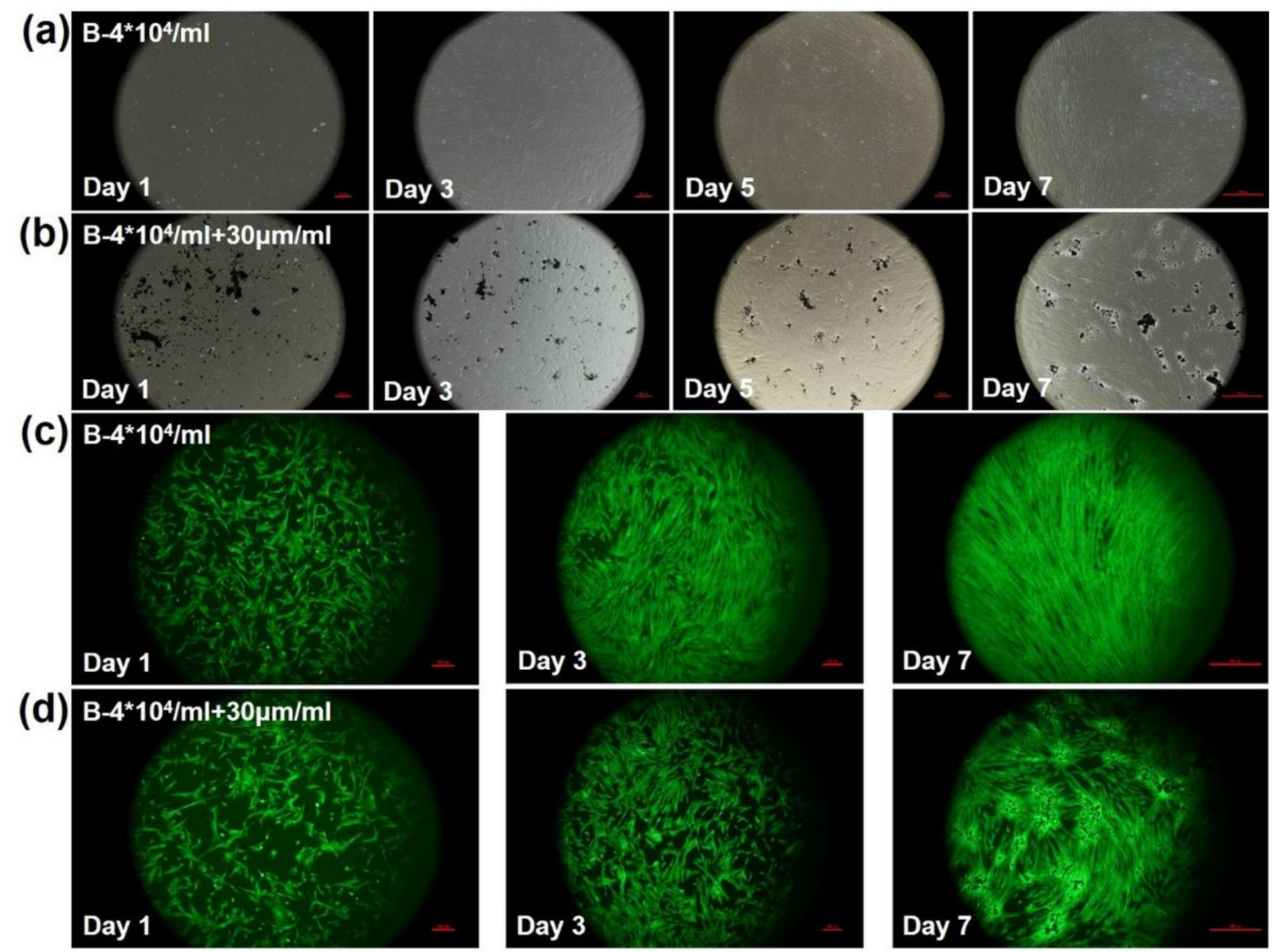

Figure 5

Transmitted light images and fluorescence images of group B and group B + GO in 7 days of culture. (a) Transmitted light images of group B $(4.0 \times 104 / \mathrm{ml})$. (b) Transmitted light images of group B $(4.0 \times 104 / \mathrm{ml})$ $+\mathrm{GO}(30 \mu \mathrm{g} / \mathrm{ml})$. (c) Fluorescence images of group B $(4.0 \times 104 / \mathrm{ml})$. (d) Fluorescence images of group $B$ $(4.0 \times 104 / \mathrm{ml})+\mathrm{GO}(30 \mu \mathrm{g} / \mathrm{ml})$. 


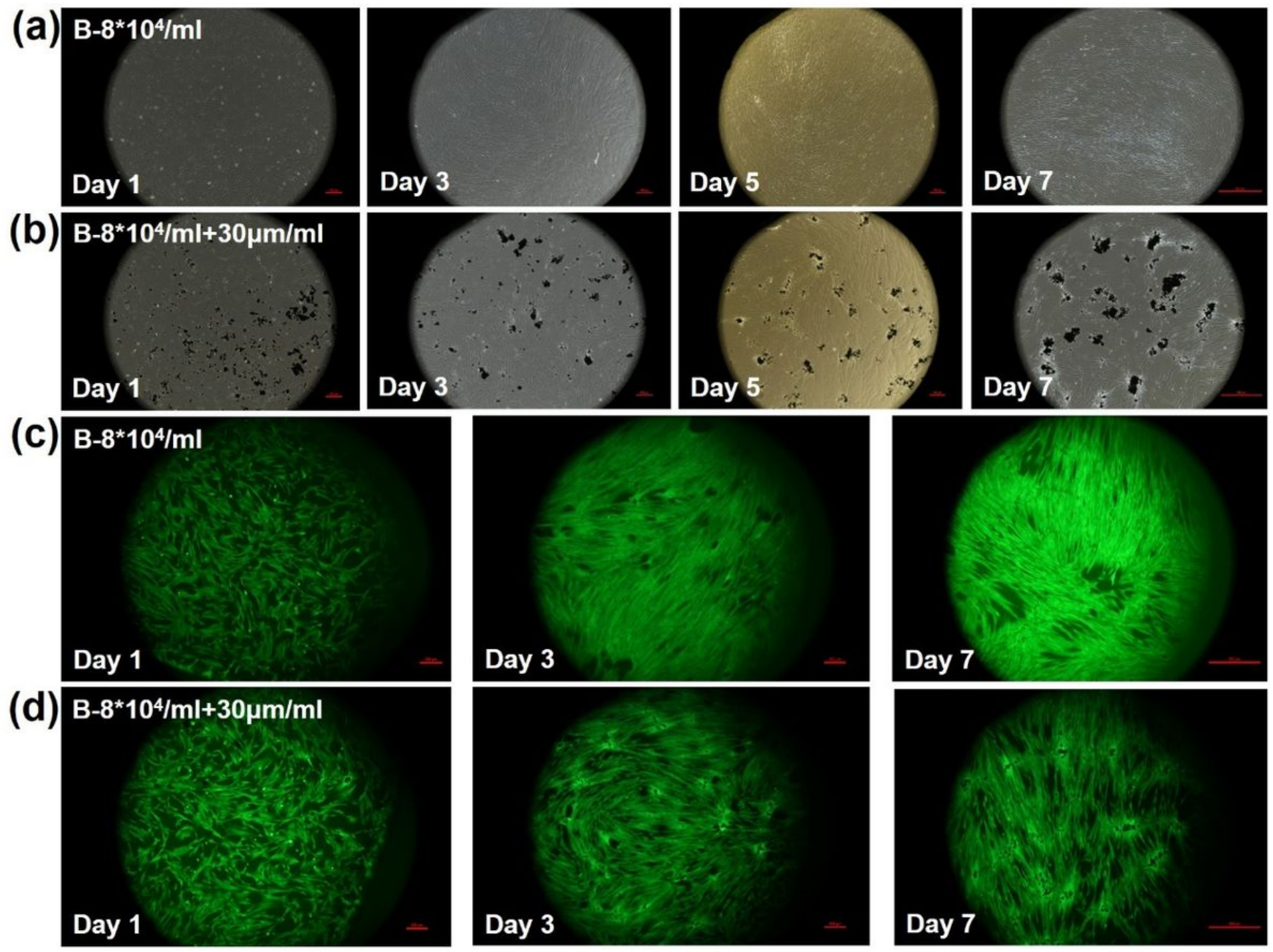

Figure 6

Transmitted light images and fluorescence images of group B and group B $+\mathrm{GO}$ in 7 days of culture. (a) Transmitted light images of group B $(8.0 \times 104 / \mathrm{ml})$. (b) Transmitted light images of group B $(8.0 \times 104 / \mathrm{ml})$ $+\mathrm{GO}(30 \mu \mathrm{g} / \mathrm{ml})$. (c) Fluorescence images of group B $(8.0 \times 104 / \mathrm{ml})$. (d) Fluorescence images of group B $(8.0 \times 104 / \mathrm{ml})+\mathrm{GO}(30 \mu \mathrm{g} / \mathrm{ml})$. 


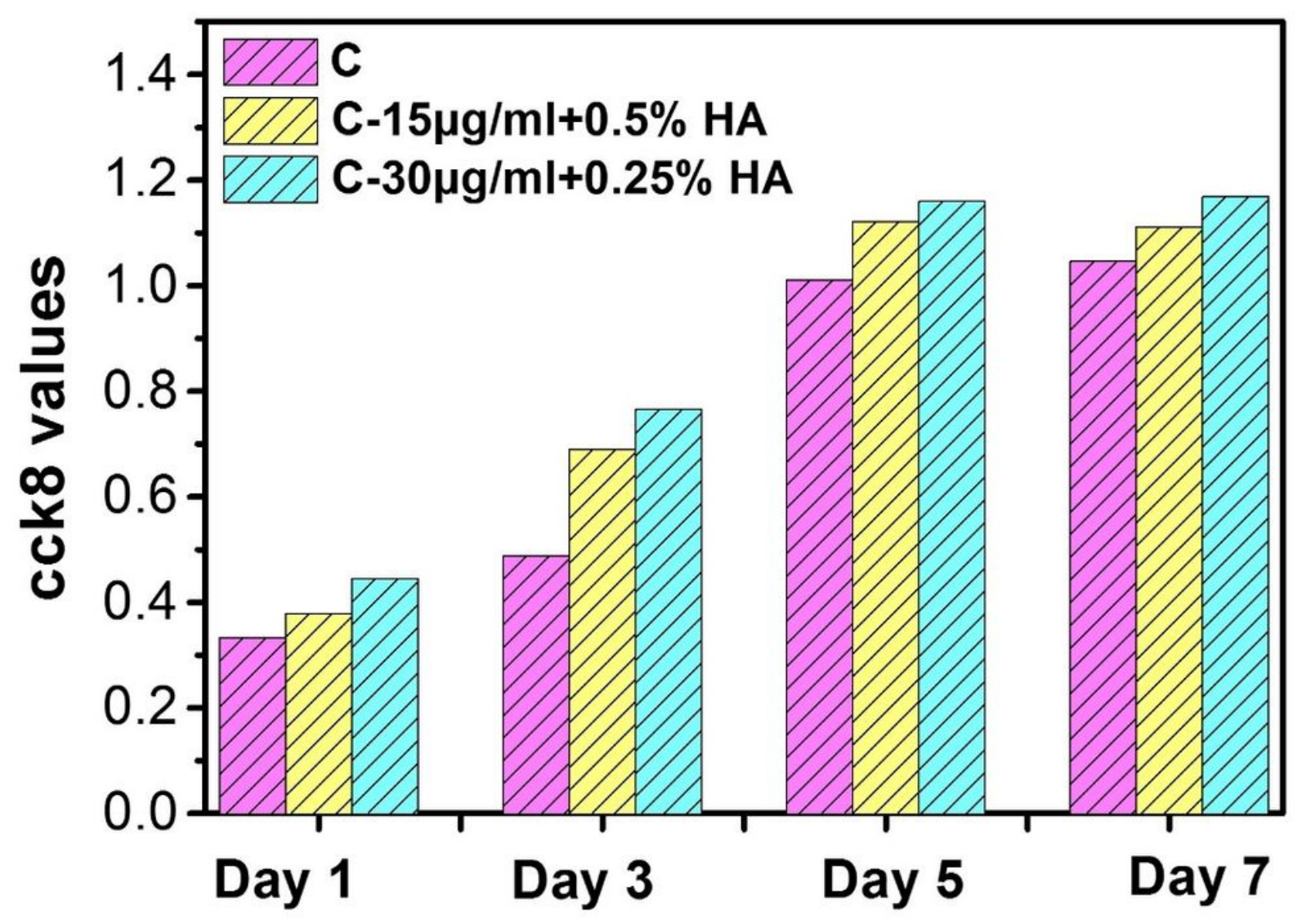

Figure 7

The cck8 detection values trend of group C (UCMSC cell concentration was $2.0 \times 104 / \mathrm{ml})$, group C (UCMSC cell concentration was $2.0 \times 104 / \mathrm{ml})+\mathrm{GO}(15 \mu \mathrm{g} / \mathrm{ml})+\mathrm{HA}(0.5 \%)$ and group C (UCMSC cell concentration was $2.0 \times 104 / \mathrm{ml})+\mathrm{GO}(30 \mu \mathrm{g} / \mathrm{ml})+\mathrm{HA}(0.25 \%)$ after 7 days of culture. 
(a) C-Control

(b) $\mathrm{C}-+15 \mu \mathrm{m} / \mathrm{ml}+0.5 \%$ HA

Day 1

(C) $\mathrm{C}-+30 \mu \mathrm{m} / \mathrm{ml}+0.25 \%$ HA

(d) C-Control

Day 1

(e) $\mathrm{C}-+15 \mu \mathrm{m} / \mathrm{ml}+0.5 \% \mathrm{HA}$

Day 1

(f) $\mathrm{C}-+30 \mu \mathrm{m} / \mathrm{ml}+0.25 \% \mathrm{HA}$

Day 1
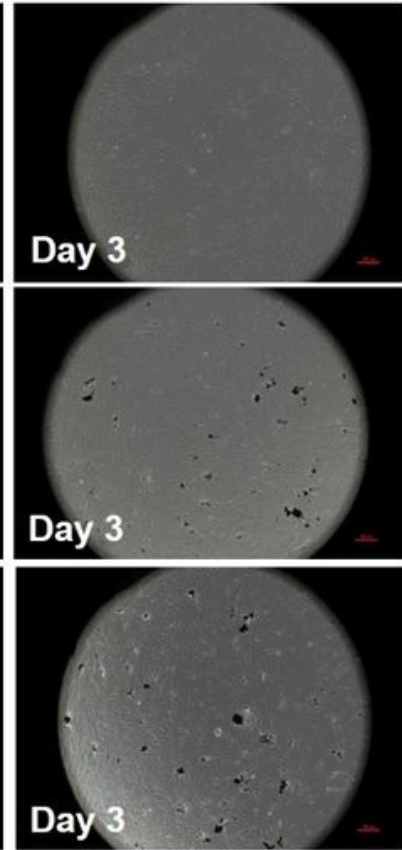

\section{Day 5}

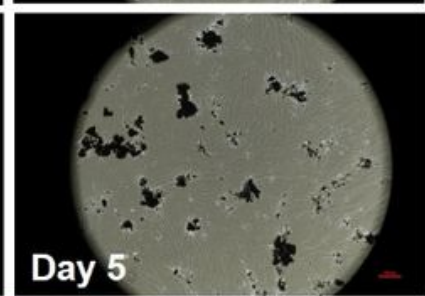

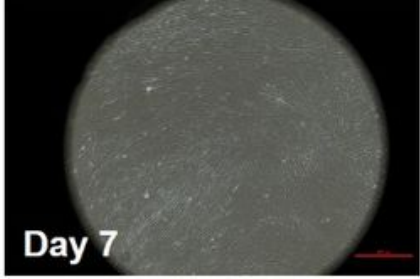
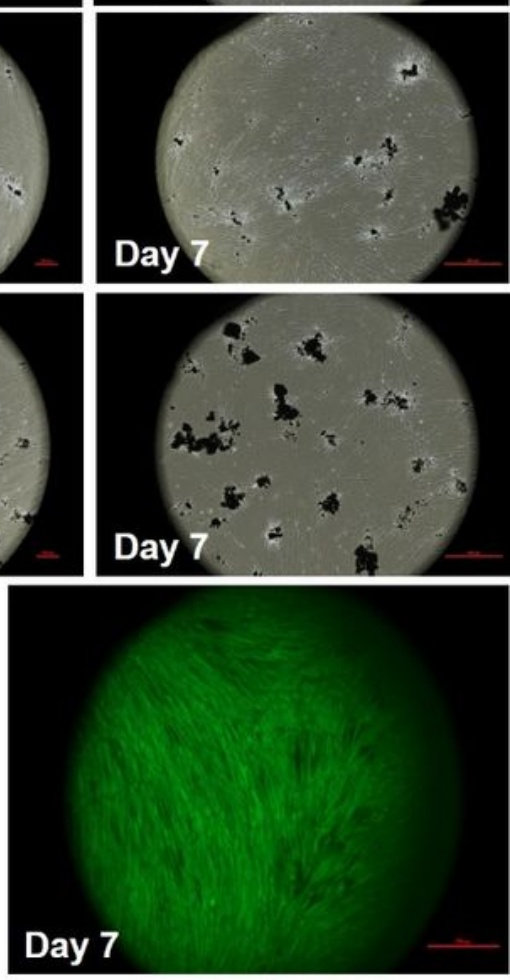

Day 3

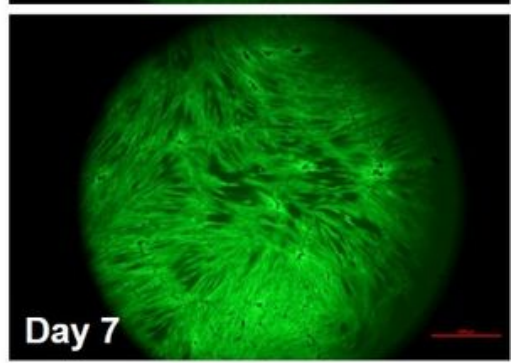

Day 3
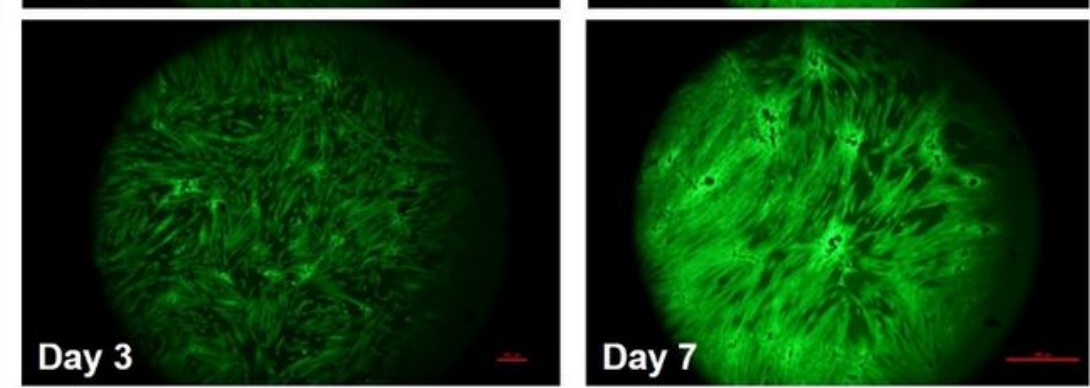

Figure 8

Transmitted light images and fluorescence images of group C and group C + GO in 7 days of culture. (a) Transmitted light images of group C $(2.0 \times 104 / \mathrm{ml})$. (b) Transmitted light images of group C $(2.0 \times 104 / \mathrm{ml})$ + GO $(15 \mu \mathrm{g} / \mathrm{ml})+\mathrm{HA}(0.5 \%)$. (c) Transmitted light images of group C $(2.0 \times 104 / \mathrm{ml})+\mathrm{GO}(30 \mu \mathrm{g} / \mathrm{ml})+\mathrm{HA}$ (0.25\%). (d) Fluorescence images of group C $(2.0 \times 104 / \mathrm{ml})$. (e) Fluorescence images of group C 
$(2.0 \times 104 / \mathrm{ml})+\mathrm{GO}(15 \mu \mathrm{g} / \mathrm{ml})+\mathrm{HA}(0.5 \%)$. (f) Fluorescence images of group C $(2.0 \times 104 / \mathrm{ml})+\mathrm{GO}$ $(30 \mu \mathrm{g} / \mathrm{ml})+\mathrm{HA}(0.25 \%)$.

\section{Supplementary Files}

This is a list of supplementary files associated with this preprint. Click to download.

- SupportingInformation.docx 